\title{
Hubungan Pekerjaan dan Penghasilan dengan Konsumsi Minuman Keras pada Remaja di Ngemplak Seneng Manisrenggo Klaten Jawa Tengah
}

\author{
Teguh Santoso ${ }^{1}$, Falasifah Ani Yuniarti ${ }^{2}$, Rossida $^{1}$
}

\begin{abstract}
Background: Alcohol consumption in the world at 2015 in the amount of 6.3 litter pure alcohol, the consumer average of age around above 15 years old. Drinking alcohol underage has impact on physical and mental disorders.
\end{abstract}

Purpose: Knowing the relation between employment and income with alcohol consumption in adolescents at Ngemplak Seneng Manisrenggo Klaten Cental Java.

Research method: This is a quantitative descriptive study with cross-sectional design. In this used total sampling, 35 subjects participating. Data obtained using question and analyzed by using Chi Square and multiple Regression.

Result: Employment (31.4\%), income (40.0\%), and alcohol consumption (62.9\%). From statistical analysis, employment with alcohol consumption shows the $p$ value $(0.011)$ and income with alcohol consumption (0.006). The result from employment and income with alcohol consumption shows the $r$ value (0.819).

Conclusion: There is a significant relation between employment and income with alcohol consumption in adolescents.

Keywords: Employment and income, alcohol consumption.

\section{Pendahuluan}

Di dunia diperkirakan remaja berjumlah 1,2 milyar atau $18 \%$ dari jumlah penduduk dunia (WHO, 2014). Pada tahun 2012, terdapat 3,3 juta kematian 5,9\% disebabkan oleh konsumsi alcohol. Diseluruh dunia, konsumsi alkohol pada tahun

\footnotetext{
Afiliasi Penulis

1 | Nursing Programme of STIKes Guna Bangsa Yogyakarta

2 | Nursing Magister Study Programme of Universitas

Muhammadiyah Yogyakarta

Korespondensi kepada

T. Santoso

tg.santoso21@gmail.com
}

2015 berjumlah 6,3 liter alkohol murni per orang (berusia $\geq 15$ tahun) (WHO, 2015).

Remaja menurut Badan Kependudukan dan Keluarga Berencana (BKKBN) adalah penduduk dalam rentang usia 10-24 tahun dan belum menikah. Jumlah kelompok usia 10-19 tahun di Indonesia menurut sensus penduduk 2010 sebanyak 43,5 juta atau $18 \%$ dari jumlah penduduk.

Remaja masa kini lebih banyak menghadapi tuntutan dan harapan, demikian bahaya (pergaulan bebas) dan godaan (ingin mencoba, ingin menghilangkan stress dan ikut-ikut teman bergaul) dengan cara mudah, yang lebih kompleks. Banyak dari remaja yang menghadapi masalah atau menghindari masalah dengan mencari ketenangan 
melalui minum minuman keras meskipun minum keras dibawah usia 21 adalah ilegal (Santrock, 2003).

Konsumsi alkohol di kalangan remaja merupakan masalah kesehatan serius. Minum alkohol dibawah umur berdampak pada bagi kesehatan dan sosial (Lee et al, 2001). Konsumsi alkohol dalam jangka waktu yang lama dapat mengakibatkan, penyakit jantung koroner, tekanan darah tinggi, penyakit cerebrovaskuler, stroke, serosis hepatis, dan penyakit saluran pencernaan (NIAAA, 2011).

Berdasarkan data Sensus Penduduk 2010, Jumlah angkatan kerja sebanyak 172.070.339 jiwa, 66,06 persen diantaranya adalah remaja usia 15-24 tahun, jumlah tersebut menunjukkan bahwa jumlah remaja cukup besar yang termasuk dalam angkatan kerja.

Menurut Sari (2014), bahwa alasan-alasan untuk berhenti dari sekolah dan kemudian bekerja adalah kemauan diri sendiri, yang dimana masih adanya pandangan mengenai materi dan mengenai dunia pendidikan, lingkungan, kenakalan remaja, dan ekonomi yang lemah.

Dari uraian tersebut, penelitian ini bertujuan untuk mengetahui hubungan antara pekerjaan dan penghasilan dengan konsumsi minuman keras.

Tabel 1 | Pekerjaan dan penghasilan remaja di Ngemplak Seneng Manisrenggo Klaten Jawa Tengah

\begin{tabular}{|c|c|c|c|}
\hline Karakteristik & Kategori & $\mathrm{N}$ & $F(\%)$ \\
\hline \multirow[t]{7}{*}{ Pekerjaan } & PNS & 0 & 0.0 \\
\hline & Swasta & 6 & 11.4 \\
\hline & Petani & 4 & 17.1 \\
\hline & Buruh & 5 & 14.3 \\
\hline & Serabutan & 11 & 31.4 \\
\hline & Lain-lain & 9 & 25.7 \\
\hline & Total & 35 & 100 \\
\hline \multirow[t]{6}{*}{ Penghasilan } & Rp. 500.000 - Rp. 1.000 .000 & 14 & 40.0 \\
\hline & Rp. $1.000 .000-$ Rp. 1.500 .000 & 10 & 28.6 \\
\hline & Rp. $1.500 .000-$ Rp. 2.000 .000 & 2 & 5.7 \\
\hline & Rp. $2.000 .000-$ Rp. 2.500 .000 & 3 & 8.6 \\
\hline & > Rp. 2.500 .000 & 6 & 17.1 \\
\hline & Total & 35 & 100 \\
\hline
\end{tabular}

\section{Metode}

Penelitian ini merupakan penelitian diskriptif kuantitatif, dengan rancangan penelitian Cross Sectional. Penelitian ini dilakukan di Ngemplak Seneng Manisrenggo Klaten Jawa Tengah pada bulan januari 2017.

Sample dalam penelitian ini berjumlah 35 responden dengan menggunakan total sampling. Kriteria inklusi adaah remaja sudah bekerja dan remaja yang pernah mengkonsumsi alkohol sedangkan kriteria ekslusinya yaitu remaja yang sekolah, remaja yang tidak memiliki penghasilan dan remaja yang tidak pernah mengkonsumsi alkohol.

Pengumpulan data dengan menggunakan kuesioner. Kuesioner ini terdiri dari 7 item pertanyaan dengan memilih jawaban ya atau tidak, yang terbagi dalam bentuk pilihan ganda dan esay untuk mengetahui pekerjaan dan penghasilan. Penilaian konsumsi minuman keras dengan menggunakan kuesioner dari WHO, 2001 "The Alkohol Use Disorders Identification Test: SelfReport Version". Yang telah dilakukan back translation.

Data yang diperoleh selanjutnya diolah menggunakan software statistik. Pada penelitian ini peneliti menggunakan tiga macam analisis, yaitu univariat, bivariat menggunakan analisis Chi Square dan multivariat menggunakan multiple Regression atau regresi berganda.

\section{Hasil}

Remaja yang bekerja serabutan berjumlah 11 atau $31,4 \%$ dan penghasilan tertinggi adalah Rp.500.000-1.000.000 dapat dilihat pada tabel 1.

Tingkat konsumsi minuman keras pada remaja dapat dilihat pada tabel 2, di mana tingkat konsumsi tertinggi dalam kategori ringan sebanyak

Tabel 2 | Tingkat konsumsi minuman keras pada remaja.

\begin{tabular}{cccc} 
Penilaian & Kategori & N & $\mathbf{F}(\%)$ \\
\hline $\begin{array}{c}\text { Konsumsi } \\
\text { minuman } \\
\text { keras }\end{array}$ & Ringan & 22 & 62,9 \\
\hline Total & Bedang & 7 & 20,0 \\
\hline
\end{tabular}


Tabel 3 | Hubungan pekerjaan dengan konsumsi minuman keras.

\begin{tabular}{|c|c|c|c|c|c|c|c|}
\hline \multirow{3}{*}{ Jenis pekerjaan } & \multicolumn{6}{|c|}{ Tingkat konsumsi minuman keras } & \multirow{3}{*}{ Nilai p } \\
\hline & \multicolumn{2}{|c|}{ Ringan } & \multicolumn{2}{|c|}{ Sedang } & \multicolumn{2}{|c|}{ Berat } & \\
\hline & $\mathrm{N}$ & $F(\%)$ & $\mathrm{N}$ & $F(\%)$ & $\mathrm{N}$ & $F(\%)$ & \\
\hline PNS & 0 & 0 & 0 & 0 & 0 & 0 & \multirow{6}{*}{0,011} \\
\hline Swasta & 4 & 11,4 & 0 & 0 & 0 & 0 & \\
\hline Petani & 6 & 17,1 & 0 & 0 & 0 & 0 & \\
\hline Buruh & 5 & 14,3 & 0 & 0 & 0 & 0 & \\
\hline Serabutan & 6 & 17,1 & 3 & 8,6 & 2 & 5,7 & \\
\hline Lain-lain & 1 & 2,9 & 4 & 11,4 & 4 & 11,4 & \\
\hline Total & 22 & 62,8 & 7 & 20 & 6 & 17,1 & \\
\hline
\end{tabular}

Tabel 4 | Hubungan penghasilan dengan konsumsi minuman keras.

\begin{tabular}{|c|c|c|c|c|c|c|c|}
\hline \multirow{3}{*}{ Penghasilan } & \multicolumn{6}{|c|}{ Tingkat konsumsi minuman keras } & \multirow{3}{*}{ Nilai $p$} \\
\hline & \multicolumn{2}{|c|}{ Ringan } & \multicolumn{2}{|c|}{ Sedang } & \multicolumn{2}{|c|}{ Berat } & \\
\hline & $\mathrm{N}$ & $F(\%)$ & $\mathrm{N}$ & $F(\%)$ & $\mathrm{N}$ & $F(\%)$ & \\
\hline Rp. 500.000 - Rp. 1.000 .000 & 12 & 34,3 & 2 & 5,8 & 0 & 0 & \multirow{5}{*}{0,006} \\
\hline Rp. 1.000 .000 - Rp. 1.500 .000 & 7 & 20,3 & 2 & 5,8 & 1 & 2,9 & \\
\hline Rp. 1.500 .000 - Rp. 2.000 .000 & 1 & 2,9 & 1 & 2,9 & 0 & 0 & \\
\hline Rp. 2.000 .000 - Rp. 2.500 .000 & 0 & 0 & 2 & 5,8 & 1 & 2,9 & \\
\hline > Rp. 2.500 .000 & 2 & 5,8 & 0 & 0 & 4 & 11,4 & \\
\hline Total & 22 & 62,9 & 7 & 20,0 & 6 & 17,1 & \\
\hline
\end{tabular}

22 responden atau 62,9\% dari total keseluruhan responden.

Tabel 3 dan 4 memperlihatkan hubungan pekerjaan dan penghasilan terhadap konsumsi minuman keras dengan masing-masing nilai $p$ adalah 0,011 dan 0.006, serta nilai $r$ adalah 0.819 pada tabel 5. Hal tersebut dapat diartikan bahwa pekerjaan dan penghasilan memiliki hubungan erat dan bermakna terhadap konsumsi minuman keras.

\section{Pembahasan}

Hubungan antara pekerjaan dan penghasilan dengan konsumsi minuman keras adalah 0,819, nilai tersebut menunjukkan bahwa nilai $r$ semakin mendekati 0,1. Hal ini menunjukkan bahwa terdapat hubungan yang erat dan signifikan antara pekerjaan dan penghasilan dengan konsumsi minuman keras pada remaja di Ngemplak Seneng Manisrenggo Klaten Jawa Tengah.
Hasil penelitian ini mendukung penelitian Sari (2014) yang menyatakan bahwa alasan pilihan untuk berhenti dari sekolah dan kemudian bekerja karena kemauan sendiri. Dimana masih adanya pandangan materi dan mengenai dunia pendidikan, lingkungan, kenakalan remaja dan ekonomi yang lemah. Pekerjaan menandakan sebuah faktor sosial yang kompleks dan psikologi yang mencerminkan kecerdasan, pendidikan, kepribadian, ambisi, status sosial, dan gaya hidup.

Pekerjaan digunakan untuk suatu tugas atau kerja yang menghasilkan sebuah karya yang

Tabel 5 | Hubungan antara pekerjaan dan penghasilan dengan konsumsi minuman keras.

\begin{tabular}{cccc} 
Kategori & $\begin{array}{c}\text { Konsumsi } \\
\text { minuman } \\
\text { keras }\end{array}$ & Nilai p & $r$ \\
\hline Pekerjaan & 19,718 & 0,011 & 0,819 \\
\hline Penghasilan & 21,694 & 0,006 & \\
\hline
\end{tabular}


bernilai imbalan dalam bentuk uang atau materi bagi seseorang (Depkes RI, 2009). Salah satu tujuan untuk mendapatkan penghasilan adalah untuk menunjang kehidupan selanjutnya dan penghasilan bisa didapatkan dengan pekerjaan yang ditekuni. Pada umumnya masyarakat selalu mencari tingkat pendapatan yang tinggi untuk memenuhi kebutuhan rumah tangganya, akan tetapi dibatasi oleh beberapa faktor (Nazir, 2010).

Konsumsi alkohol memiliki banyak hubungan dengan peran pekerjaan. Tingginya tingkat konsumsi minuman keras ditempat kerja dikarenakan kesempatan untuk mendapatkan minuman yang relatif murah dan mudah, bila bergabung dengan rekan-rekan sesama pekerja dapat menjadi alasan yang sangat kuat. Berdasarkan penelitian Jakoby (2015) yang menyimpulkan bahwa secara keseluruhan orang yang lebih banyak uang atau penghasilan akan cenderung mengkonsumsi minum minuman keras dan dengan jumlah yang lebih banyak.

Adanya penghasilan yang dimiliki, remaja dapat bebas menggunakan penghasilannya untuk berkumpul bersama dengan temannya. Hasil penelitian ini mendukung Subiyantoro (2016) yang menyatakan bahwa faktor yang domain mempengaruhi remaja dalam mengkonsumsi minuman beralkohol adalah faktor lingkungan. Penelitian Wulandari (2014), menyimpulkan bahwa faktor terbesar yang membuat orang senang ditempat kerja adalah hubungan positif dengan orang lain.

\section{Kesimpulan}

Berdasarkan hasil analisis data maka dapat di simpulan bahwa terdapat hubungan antara pekerjaan dengan konsumsi minuman keras. Hal ini menunjukkan semakin baik pekerjaan maka semakin rendah konsumsi minuman keras atau semakin rendah jenis pekerjaan maka semakin tinggi juga konsumsi minuman keras. Kesimpulan kedua yang dapat dikemukakan adalah terdapat hubungan antara penghasilan dengan konsumsi minuman keras. Semakin tinggi penghasilan maka semakin tinggi konsumsi minuman keras dan begitu pula sebaliknya.

Hasil penelitian ini dapat dijadikan bahan pengkajian kesehatan komunitas dan anak dalam meningkatkan promosi kesehatan terutama mengenai konsumsi minuman keras pada remaja, bagi remaja di Ngemplak Seneng Manisrenggo Klaten Jawa Tengah. Remaja khususnya diharapkan dapat menggunakan penghasilan dengan sebaikbaiknya dan tidak digunakan untuk konsumsi minuman keras serta membatu orang tua atau orang sekitar yang membutuhkan. Penelitian lebih lanjut sangat diperlukan untuk mengetahui faktorfaktor yang mempengaruhi remja dalam mengkonsumsi minuman keras.

\section{Bibliografi}

1. BKKBN. 2011. Profil Hasil Pendataan Keluarga Tahun 2011. Jakarta: Badan Kependudukan dan Keluarga Berencana Nasional Direktorat Pelaporan dan Statistik.

2. Depkes RI. 2009. Profil kesehatan indonesia. Jakarta: Departemen Republik Indonesia.

3. Nazir. 2010. Analisis Determinan Pendapatan Pedagang Kaki Lima di Kabupaten Aceh Utara. Tesis. Medan. Universitas Sumatera Utara.

4. NIAAA, 2011. Alcohol Facts and Statistics. Diakses pada tanggal 09 Oktober 2016 dari https://www.niaaa.nih.gov/alcohol-health/overviewalcohol-consumption/alcohol-facts-and-statistics.

5. Sanstrock, J.W. 2003. Adolescence (Perkembangan Remaja). Terjemahan. Jakarta : Erlangga.

6. Sari, F.R. D. 2014. Pilihan remaja pada dunia kerja di kampung Glendongan Dusun Tambakbayan, Caturtunggal, Depok, Sleman, Yogyakarta. Proposal Skripsi : SI IImu Kesejahteraan Sosial UIN Sunan Kalijaga Yogyakarta.

7. Subiyantoro. 2016. Faktor yang mempengaruhi remaja mengkonsumsi minuman beralkohol di it $07 \mathrm{rw}$ 06 kelurahan pacar kembang kecamatan tambak sari surabaya. Skripsi : Akademi Keperawatan William Booth Surabaya.

8. World Health Organization. 2001. Audit : The Alcohol Use Disorders Identification Test. Diakses pada tanggal 13 november 2016 dari http://www.talkingalcohol.com/files/pdfs/WHO_audit.p df

9. World Health Organization. 2011. Global status report on alcohol and health. Diakses pada tanggal 09 oktober 2016 dari http://www.who.int/substance_abuse/publications/glo bal_alcohol_report/msbgsruprofiles.pdf

10. World Health Organization. 2014. Wordld Health Statistics. Diakses pada tanggal 09 oktober 2016 dari http://apps.who.int/iris/bitstream/10665/112738/1/978 


\section{1_eng.pdf}

11. World Health Organization. 2015. Statistics on Alcohol. Diakses pada tanggal 09 oktober 2016 dari http://content.digital.nhs.uk/catalogue/pub17712/alceng-2015-rep.pdf

12. Wulandari, S. 2014. Faktor - Faktor Kebahagiaan Di Tempat Kerja. Skripsi : Fakultas Psikologi Universitas Islam Negeri Sultan Syarif Kasim Riau. 